\title{
Specific DNA markers for detection of bacterial canker of kiwifruit in Sichuan, China
}

\author{
Yao Liu, Shujiang Li, Tian-hui Zhu* and Baolin Shao \\ College of Forestry, Sichuan Agricultural University, Ya'an 625014, Sichuan, China. \\ Accepted 19 December, 2012
}

\begin{abstract}
Bacterial canker of kiwifruit (Actinidia chinensis) has become one of the most serious factors that limit the cultivation of kiwifruit in Sichuan, China. Therefore, it is urgent to develop a rapid and precise method to detect the disease at its early infection stage. A $1300 \mathrm{bp}$ specific fragment of pathogenic bacteria was obtained by random amplified polymorphic DNA (RAPD) analysis. This fragment was cloned and sequenced. Based on the sequences of the specific fragment, a pair of specific primers (F7'/R7') that generated 994 bp single fragment only from the strains of Pseudomonas syringae pv. actinidiae were designed and synthesized. Then, for the detection of diseased kiwifruit trunk tissues collected from orchard and inoculated kiwifruit trunk tissues, the result indicated that the genomic DNA of $P$. syringae pv. actinidiae can be detected by the specific primers. The sensitivity of the primer set for genomic DNA of $P$. syringae pv. actinidiae was $100 \mathrm{fg}^{-1} l^{-1}$. Compared with the designed primers with four pairs of published primers. The comparison concluded that only the primers designed in this study was specific to detect bacterial canker of kiwifruit in Sichuan. The result of this experiment showed that the designed and synthesized specific primers F7'/R7' made it possible to diagnose the kiwifruit canker rapidly and precisely at its early infection stage.
\end{abstract}

Key words: Bacterial canker, kiwifruit, primer, RAPD, SCAR, P. syringae pv. Actinidiae.

\section{INTRODUCTION}

Kiwifruit (Actinidia chinensis) is the fruit of high economic value. So many countries, such as Italy, New Zealand, Chile, Japan, Iran and China, have actively developed their planting industries. However, the occurrence of bacterial canker of kiwifruit has become one of the most serious factors that limit the cultivation of kiwifruit in these countries. The disease was first reported in Japan and USA in early 1980s (Opgcnorth et al., 1983; 1984; Serizawa et al., 1989). Subsequently, it was also observed in Korea (Koh and Lee, 1992), Iran (Mazarei and Mostofipour, 1994) and Italy (Scortichini, 1994). In China, the disease was first found in Hunan province in 1984 (Fang et al., 1990). Then within a few years, it rapidly spread to the provinces of Sichuan (Liu et al.,1996), Anhui (Cheng et al., 1995), Fujian (Lin et al., 1995) and so on. Since the disease has caused serious

\footnotetext{
*Corresponding author. E-mail: zhutianhui@yahoo.cn.
}

damages to the production of kiwifruit which is strong enough to destroy some of the orchards, it is very essential to establish efficient control strategies for the disease. Some traditional methods, such as spraying antibiotics, copper compounds or trunk injection of antibiotics, have been proved to achieve partial success in controlling the disease (Koh et al., 1996, 1999; Serizawa et al., 1989; Ushiyama, 1993). Nevertheless, the disease shows the typical symptoms two or three years after latent infection, which makes it difficult to diagnose the disease with the naked eyes. Meanwhile, chemical control is considered to be less effective after the symptoms appear. Therefore, it is very important to develop a method that can detect the disease in its early infection stage. The casual agent of bacterial canker of kiwifruit was identified as Pseudomonas syringae $p v$. actinidiae, which was first reported in Japan (Takikawa et al., 1989) and then in Italy (Scortichini, 1994). It was also demonstrated in China by many scholars (Wang et al., 1992; Zhu et al., 1993; Cheng et al., 1995). However, 
Table 1. Strains of Pseudomonas syringae pathovars or similar strains of Pseudomonas, or other genuses used in this study.

\begin{tabular}{lll}
\hline Strain & Specie or pathovars & Source \\
\hline DY10 & Pseudomonas syringae pv. actinidiae & Deyang, Sichuan, China \\
QL14 & Pseudomonas syringae pv. actinidiae & Qionglai, Sichuan, China \\
DJY08 & Pseudomonas syringae pv. actinidiae & Du Jiangyan, Sichuan, China \\
CZ20 & Pseudomonas syringae pv. actinidiae & Chongzhou, Sichuan, China \\
P2105 & Pseudomonas syringae pv. actinidiae & Chinese Academy of Forestry, Beijing,China \\
P1336 & Pseudomonas syringae pv. syringae & Chinese Academy of Forestry, Beijing,China \\
DY32 & Pseudomonas fluorescens & Deyang, Sichuan, China \\
P1368 & Pseudomonas syringae pv. morsprunorum & Chinese Academy of Forestry, Beijing,China \\
QL04 & Erwina amylovora & Qionglai, Sichuan, China \\
P2104 & Bacillus pumilus & Chinese Academy of Forestry, Beijing,China \\
P2726 & Pseudomonas eruginosa & Chinese Academy of Forestry, Beijing,China \\
P1481 & Xanthomonas oryzae & Chinese Academy of Forestry, Beijing,China \\
P2090 & Pseudomonas syringae & Chinese Academy of Forestry, Beijing,China \\
P2430 & Pseudomonas syringae pv. tomato & Chinese Academy of Forestry, Beijing,China \\
\hline
\end{tabular}

there are several similar pathovars or species, such as Pseudomonas syringae pv. syringe that causes blossom blight and Pseudomonas syringae pv. morsprunorum, to be repeatedly isolated from kiwifruit trees, which are not easy to distinguish from the pathogenic bacteria (Koh et al., 1993; Young et al., 1988; Opgcnorth et al., 1983; Koh and Lee, 1992; Takikawa et al., 1989). The traditional physiological and biochemical methods to identifying the pathovars of plant pathogenic bacteria are considered tedious and time-consuming (Schaad, 1988). Recently, the development of molecular marker technology has provided new tools for detecting the pathovars of plant pathogenic bacteria by looking directly at the level of DNA sequence and structure. Random amplified polymorphic DNA (RAPD; Williams et al., 1990) is a PCR-based technique and extremely efficient for DNA analysis in complex genomes as it is relatively inexpensive and yields information on a large number of loci without having to obtain sequence data for primer design (De Wolf et al., 2004). This technology has been widely used to identify and diagnose the plant pathogenic bacteria (Audy et al., 1996; Parry Nicholson, 1996; Sorensen et al., 1998; Koh and Nou, 2002). However, RAPD markers lack reproducibility due to mismatch annealing (Demeke et al., 1997; Karp et al., 1997; Neale and Harry, 1994). To overcome this problem associated with the RAPD analysis, RAPD markers have been converted into sequence characterized amplified region markers (SCAR; Paran and Michelmore, 1993). Several reports are available of the development of SCAR marker in many plants (Hernandez et al., 1999; Evans and James, 2003).

Although several countries have developed the specific DNA markers to detect the bacterial canker of kiwifruit (Koh and Nou, 2002; Templeton et al., 2005; George et al., 2010), there are no appropriate markers among them for the disease in China especially in Sichuan province, probably because of the geographical differences. The objective of this study was to develop an early diagnosis method which would be able to detect a latent infection of $P$. syringae $p v$. actinidiae on kiwifruit, especially for the disease which occurred in Sichuan province in China. The pathovar-specific RAPD and SCAR markers were selected in this experiment for the rapid and precise identification of $P$. syringae $p v$. actinidiae among similar pathovars or species that are isolated from kiwifruits.

\section{MATERIALS AND METHODS}

\section{Strains used and cultivating condition}

Five strains of $P$. syringae $p v$. actinidiae and nine similar pathovars or species were used in this study (Table 1). The NO.1-NO.4 strains of $P$. syringae $p v$. actinidiae were isolated from the infected trunks of kiwifruit trees which were collected in Deyang, Qionglai, Du Jiangyan, and Chongzhou respectively, and identified as the agent of bacterial canker of kiwifruit with the pathogenicity, bacteriological study and molecular identification based on the 16S rDNA sequences. The NO.7 and NO.9 strains were also isolated from the infected trunks, but identified as the other species rather than the pathogenic bacteria. The other eight strains were all kindly provided by the Research Institute of Forestry Ecology, Environment and Conservation, Chinese Academy of Forestry, China. A single colony of each strain was isolated on the peptone-sucrose-agar (PSA; peptone $20 \%$, sucrose $20 \%$, agar $15 \%$, $\mathrm{pH} 6.8$ ) medium for the experiment.

$P$. syringae $p v$. actinidiae and all of the other strains were transferred onto fresh PSA medium, and cultivated at $25^{\circ} \mathrm{C}$.

\section{Extraction of genomic DNA}

Cultures for DNA extraction were grown overnight in Luria-Bertani (LB; tryptone $10 \mathrm{~g} / \mathrm{L}$, Yeast extract $5 \mathrm{~g} / \mathrm{L}, \mathrm{NaCl} 10 \mathrm{~g} / \mathrm{L}, \mathrm{pH} 7.0$ ) medium at $26^{\circ} \mathrm{C}$ on a rotating shaker at a speed of $250 \mathrm{rpm}$. DNA 
was extracted by TIANamp Bacteria DNA Kit (Tiangen, China). The concentration and quality of DNA samples were estimated by comparing band intensities on agarose gel and by measuring the $260 \mathrm{~nm} / 280 \mathrm{~nm}$ absorbance ratio.

\section{Extraction of kiwifruit tissue DNA}

All the kiwifruit tissue DNA was extracted by TIANamp Plant Genomic DNA Kit (Tiangen, China). Then, the samples were tested by the same method as the genomic DNA of strains.

\section{RAPD analysis}

One hundred and twenty random primers, including 40 commercial 10-mer oligonucleotide primers and 80 commercial 12-mer oligonucleotide primers (Sangon Biotech, Shanghai, China), were used to select primers for screening the specific fragment of $P$. syringae $p v$. actinidiae. Amplification was performed in a total volume of a $25 \mu \mathrm{l}$ reaction mixture with 50 pmol of primer, $100 \mathrm{ng}$ of genomic DNA, 1 Unit of Taq DNA polymerase, 10x reaction buffer $\left(500 \mathrm{mM} \mathrm{KCl}, 100 \mathrm{mM}\right.$ of Tris- $\mathrm{HCl} \mathrm{pH} 8.3,25 \mathrm{mM}$ of $\mathrm{MgCl}_{2}, 0.01 \%$ of gelatin), $10 \mathrm{mM}$ of dNTP (dCTP, dGTP, dATP, dTTP), and extra sterilized distilled water. The conditions of DNA amplification were optimized and followed the procedure of Williams et al. (1990) with few modifications. The PCR program consisted of an initial denaturation of $5 \mathrm{~min}$ at $94^{\circ} \mathrm{C}$, followed by 40 cycles at $94^{\circ} \mathrm{C}$ for 60 $\mathrm{s}$ (denaturation), $36^{\circ} \mathrm{C}$ for $60 \mathrm{~s}$ (annealing) and $72^{\circ} \mathrm{C}$ for $2 \mathrm{~min}$ (extension), with an additional extension period of $10 \mathrm{~min}$ at $72^{\circ} \mathrm{C}$. A negative control, without genomic DNA, was run with every set of samples to confirm that no contaminating DNA was present in the reaction. Amplifications were carried out in a Mastercycler (Mastercycler Gradient, Eppendorf, Germany). The amplified PCR products were separated by electrophoresis on $1.5 \%$ agarose gels in $1 \times$ TAE buffer, visualized and imaged by gel documentation system (GelDoc 2000, Bio-Rad, USA) after staining with ethidium bromide.

\section{Cloning and sequencing of the specific DNA fragment}

The selected specific DNA fragment was isolated from the gel by TIANgel Midi Purification Kit (Tiangen, China) and cloned into PMD18-T Vector (TaKaRa, Dalian, China). Plasmid DNA was extracted by the alkaline lysis method and harvested by centrifugation at $12,000 \mathrm{rpm}$ for $20 \mathrm{~min}$ at $4^{\circ} \mathrm{C}$ after incubation on ice for $20 \mathrm{~min}$ with the PEG solution (20\% of polyethylene glycol, $2.5 \mathrm{M}$ of $\mathrm{NaCl}$ ). For determining the sequences of specific DNA fragment, the purified plasmid DNA was used as a template to amplify the inserted DNA. The nucleotide sequence of the cloned DNA was sequenced by the Sangon Biotech (Shanghai, China).

\section{Establish of sequence characterized amplified regions (SCAR) markers}

Based on the sequence of a specific DNA fragment (1300 bp) of $P$. syringae $p v$. actinidiae, the forward and reverse primers were designed by extending the original twelve bases of RAPD primer. The designed SCAR primers (F7'/R7') were synthesized by Sangon Biotech (Shanghai, China).

\section{Exploration of the optimal annealing temperature}

PCR conditions for genomic DNA amplification with SCAR primers were the same as for RAPD analysis, except for the annealing temperatures. Twelve annealing temperature gradient have been set by the Gradient PCR instrument from 55 to $65^{\circ} \mathrm{C}$ automatically, that is $55,55.2,55.7,56.8,57.8,59.1,60.5,61.8,63.1,64.2,65$, $65.5^{\circ} \mathrm{C}$. Then, PCR amplifications were conducted with the specific primers at the different annealing temperature in order to explore the optimal annealing temperature.

\section{Specificity detection of the SCAR markers}

The genomic DNA of strains listed in Table 1 were amplified by the specific primers (F7'/R7') respectively, with sterilized distilled water as the control. The PCR reactions were conducted at the explored optimal annealing temperature and the other PCR conditions for the test were the same as for RAPD analysis.

\section{Specificity detection of pathogenic bacteria in kiwifruit trunk tissues}

The genomic DNA of $P$. syringae $p v$. actinidiae and the genomic DNA of trunk tissues of diseased kiwifruit collected from orchard and inoculated kiwifruit were amplified by the specific primers (F7'/R7') respectively, with healthy trunk tissues and sterilized distilled water as the control. The PCR reactions were conducted according to the above descriptions. Then, isolated the pathogenic bacteria from the tissues which have been detected pathogens by molecular method, and identified the isolates with the pathogenicity, bacteriological study and molecular identification based on the $16 \mathrm{~S}$ rDNA sequences to see whether the results are consistent with the molecular detection.

\section{Sensitivity test of the SCAR markers}

The concentration of the extracted genomic DNA of $P$. syringae $p v$. actinidiae have been determined by the nucleic acid concentration detector, and then diluted to 6 concentration gradient, that is $1 \mathrm{ng}$

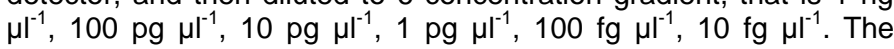
different concentrations of genomic DNA were amplified by the specific primers with sterilized distilled water as control. The other PCR conditions were the same as the above descriptions.

\section{Testing other published primers}

Using four pairs of published primers (Table 2) amplified the genomic DNA of $P$. syringae $p v$. actinidiae and other two similar pathovars or species ( $P$. syringae $p v$. syringae and $P$. syringae) respectively. PCR conditions were the same as for SCAR primers. The PCR products were also screened by electrophoresis on $1.5 \%$ agarose gels in 1×TAE buffer, visualized and imaged by gel documentation system (GelDoc 2000, Bio-Rad, USA) after staining with ethidium bromide.

\section{RESULTS}

\section{Screening of specific RAPD primers for the pathogenic bacteria}

According to the RAPD profile (Figure 1), only the primer P7 (5'-CGCAGCCGAGAT-3') repeatedly produced a specific, stable and distinct DNA fragment, which was produced only from the strains of $P$. syringae $p v$. actinidiae, but not from the other strains. The size of the 
Table 2. The sequences of four pairs of published primers.

\begin{tabular}{|c|c|c|c|c|}
\hline Primer pair & Sense & Product size (bp) & Sequences (5'-3') & Reference \\
\hline KNF & Forward & 492 & CACGATACATGGGCTTATGC & Koh and Nou \\
\hline KNR & Reverse & & СТTTTСАТССАСАСАСТССG & \\
\hline PsaF1 & Forward & 280 & TTTTGCTTTGCACACCCGATTTT & George et al. (2010) \\
\hline PsaR2 & Reverse & & CACGCACCCTTCAATCAGGATG & \\
\hline ArgKF3 & Forward & 800 & TCCCCCCGGGAGGAAATTCAATGAAGATTA & Templeton et al. (2005) \\
\hline ArgKR4 & Reverse & & AACTGCAGTCAGGGGACGACTGTCTC & \\
\hline Ps.ITSF1 & Forward & 880 & GTGATTCATGACTGGGGTGA & George et al. (2010) \\
\hline Ps.ITSR2 & Reverse & & ATAACCCCAAGCAATCTGGT & \\
\hline
\end{tabular}

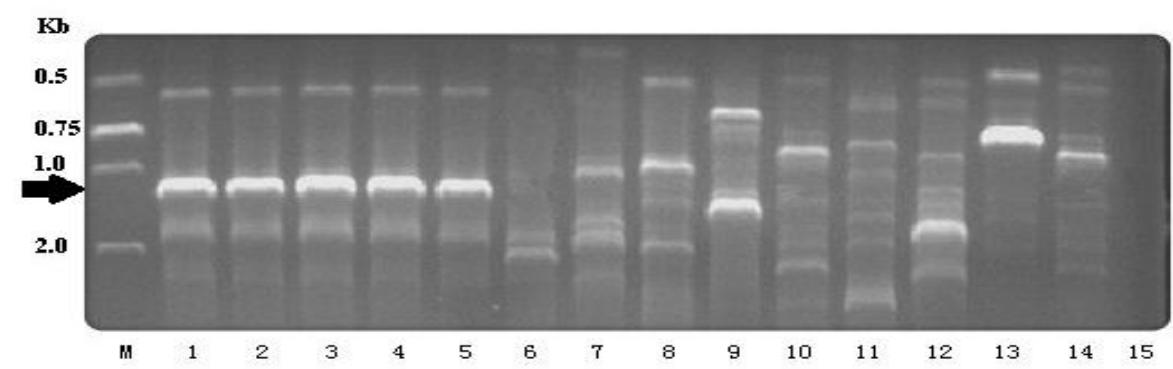

Figure 1. RAPD profiles are generated with primer P7. Lane $M, 2$ kb DNA ladder; lanes 1-14, strains of $P$. syringae pathovars or similar strains of Pseudomonas or other species listed in Table 1; lane15, CK $\left(\mathrm{ddH}_{2} \mathrm{O}\right)$.

specific fragment is about $1300 \mathrm{bp}$ that is suitable for the development of a primer to detect the pathovar-specific DNA fragment of $P$. syringae $p v$. actinidiae.

\section{Cloning and sequencing of the pathovar-specific DNA fragment}

The specific fragment generated by primer P7 was isolated from the gel, and cloned into a T-vector, followed by transforming in E.coli (JM109). Plasmid DNA was extracted from the transformations, and the target fragment was obtained and cloned. The purified plasmid DNA was sent to Sangon Biotech to determine the sequence of the specific fragment. The result of the sequencing is shown in Figure 2, which confirmed the genome size of the specific fragment is $1300 \mathrm{bp}$.

\section{Establish of SCAR markers}

Based on the sequence of the 1300 bp specific fragment, a pair of distinctive primers were designed and synthesized to examine the pathogenic bacteria of bacterial canker on kiwifruit trees. The sequences of the forward primer were found to be 5'CGATTCGCAGCCGAGATG-3' from 27 to $44 \mathrm{bp}$, by extending the original twelve bases of RAPD primer. The reverse primer was designed as 5'CTACGAGGTTAGGTTCAGAGT-3' from 1000 to $1020 \mathrm{bp}$ (Figure 2). The $\mathrm{G}+\mathrm{C}$ content of forward and reverse primer were 61.1 and $47.6 \%$ respectively.

\section{Exploration of the optimal annealing temperature}

According to the PCR profiles (Figure 3), all the 12 annealing temperature gradient could produced ideal band. But the third one is relatively more distinct and stable. Therefore, the optimal annealing temperature was determined as $56^{\circ} \mathrm{C}$.

\section{Specificity detection of the SCAR markers}

Using the synthesized primer pair amplified, the genomic 


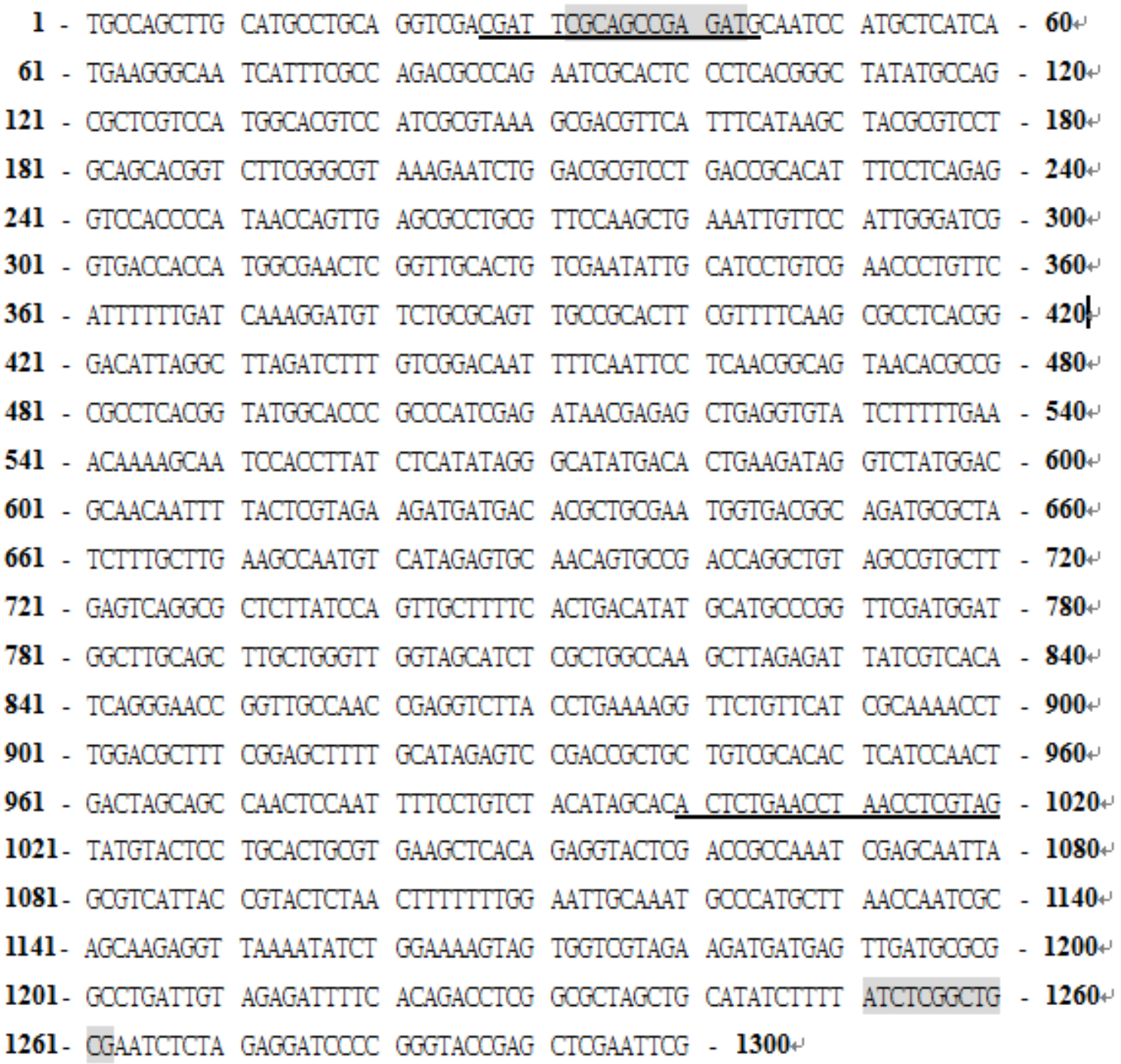

Figure 2. Nucleotide sequences of $P$. syringae $p v$. actinidiae specific DNA fragment. Underlined sequences are forward and reverse primers for the detection of a specific DNA fragment in $P$. syringar pv. actinidiae; Shadow sequences are the primer P7 that is used in RAPD analysis.

DNAs of all the strains are listed in Table 1. A single, distinct and brightly resolved band of 994 bp was obtained only from the strains of $P$. syringae $p v$. actinidiae, but not from the other strains (Figure 4). It indicated that the designed primers had certain specificity which could detect the $P$. syringae $p v$. actinidiae from other similar strains.

\section{Specificity detection of pathogenic bacteria in kiwifruit trunk tissues}

According to Figure 5, after artificial inoculation, no matter what stage the trunk tissue was, the genomic DNA of the trunk tissues could produce a $994 \mathrm{bp}$ specific band. Nevertheless, the healthy trunk tissue and sterilized distilled water could not amplify a certain band, which illustrated that the specific primers could detect the pathogenic bacteria from the host tissues and even diagnose the disease before any symptoms appears. Furthermore, the detections for the pathogenic bacteria which was isolated from the same tissues with classic method turned out to be consistent with the result of the molecular dectections.

\section{Sensitivity test of the SCAR markers}

According to Figure 6, the specific primers could amplify a distinct and stable band at the concentration of $100 \mathrm{fg}$ $\mu^{-1}$, whereas it could not produce a fragment at or under the concentration of $\left.10 \mathrm{fg}^{-1}\right|^{-1}$ as well as the sterilized 


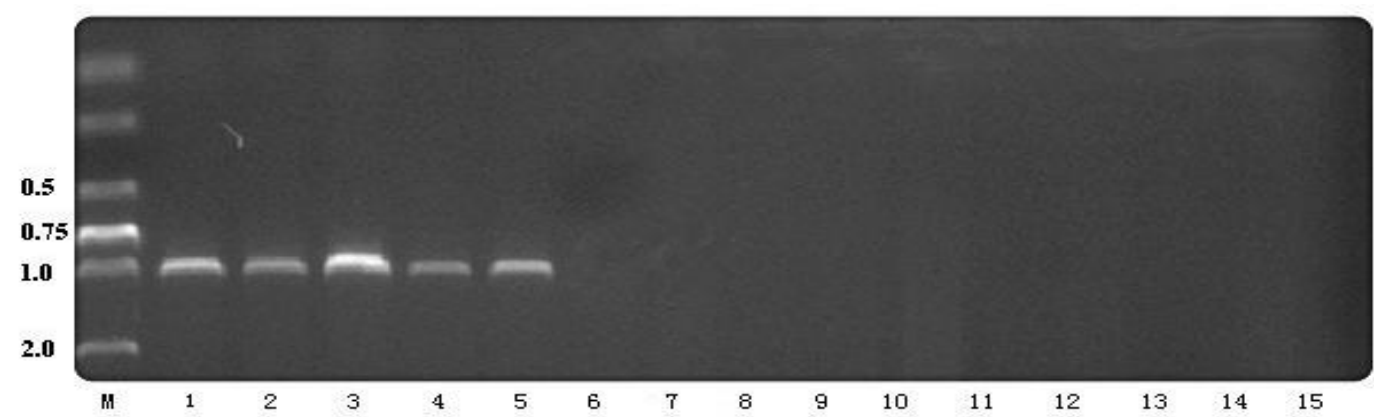

Figure 4. PCR profiles of all the strains amplified with the designed specific primer F7'/R7'. Lane M, 2 kb DNA ladder; lanes1-14, strains of $P$. syringae pathovars or similar strains of Pseudomonas or other species listed in Table 1; lane15, $\mathrm{CK}\left(\mathrm{ddH}_{2} \mathrm{O}\right)$.

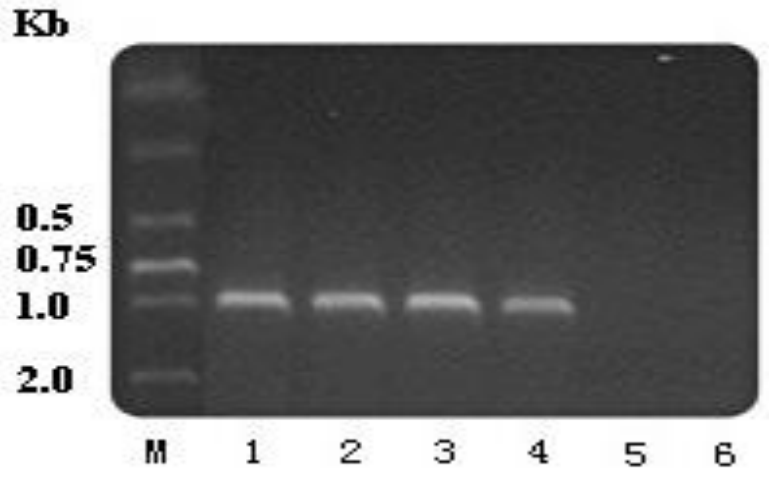

Figure 5. PCR profiles of different samples amplified with the specific primer F7'/R7'. Lane M, 2 kb DNA ladder; lane 1 , genomic DNA of $P$. syringae $p v$. actinidiae; lane 2 , DNA of early days of artificial inoculation (not show symptoms); lane 3, DNA of heavy period of artificial inoculation (has shown symptoms); lane 4, DNA of diseased kiwifruit tissues which collected from orchard; lane 5 , healthy trunk tissues; lane $6, \mathrm{CK}\left(\mathrm{dd} \mathrm{H}_{2} \mathrm{O}\right)$.

\section{Kh}

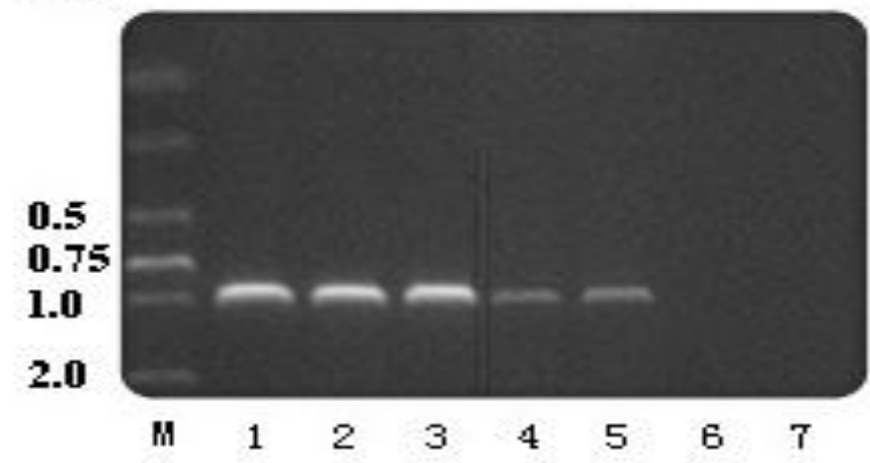

Figure 6. Sensitivity of PCR with specific primer F7'/R7' at different concentrations of DNA. Lane M, 2 kb DNA ladder; lanes 1-6 amplified products using DNA at concentration of 1

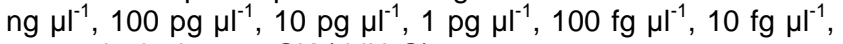
respectively; lane $7, \mathrm{CK}\left(\mathrm{ddH}_{2} \mathrm{O}\right)$. distilled water.

\section{Detection of $P$. syringae pv. actinidiae by other published primers}

The extracted genomic DNAs of $P$. syringae $p v$. actinidiae and other two similar pathovars or species $(P$. syringae $p v$. syringae and $P$. syringae) were amplified by four pairs of published primers respectively. The PCR profile showed that all of the four pairs of primers were not specific for detecting the pathogenic bacteria from the three tested strains (Figure 7). Primer KNF/KNR and Ps.ITSF1/Ps.ITSR2 could not only produce the fragment from the strains of $P$. syringae $p v$. actinidiae, but also from the other strains. And primer PsaF1/PsaR2 could hardly amplify the bands as well as primer ArgKF3/ArgKR4.

\section{DISCUSSION}

In this study, a $1300 \mathrm{bp}$ fragment that was amplified with random primer P7 by RAPD analysis was only screened from $P$. syringae $p v$. actinidiae among all the tested strains that are frequently isolated from kiwifruit trees. It is expected that the pathogenic bacteria could be identified quickly and precisely by the RAPD experiment using the random primer P7. However, the sensitivity of the RAPD reaction to a number of reaction parameters at a low annealing temperature has made it hard to generate consistent profiles even under laboratory conditions, which necessitates converting the RAPD marker into a more stable SCAR marker. But the transformation is not easy to succeed for many reasons, such as inappropriate primer design, multi-copy sequences of obtained RAPD fragment, DNA methylation and many other reasons (Sun et al., 2010). To overcome these problems, we need to design pairs of primers and explore the optimal annealing temperature and reaction conditions. There have been many cases of successful conversions (Meetu and 


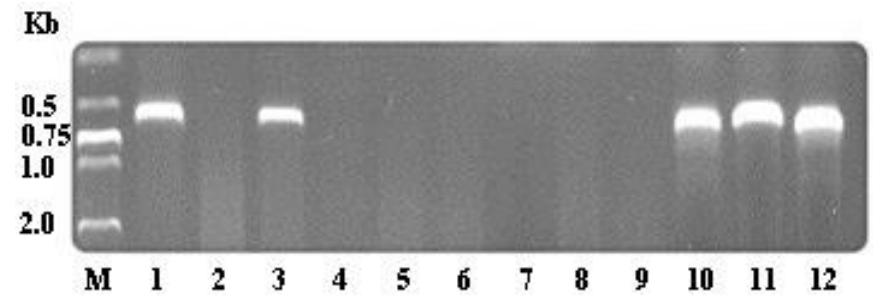

Figure 7. PCR profiles of screening of Pseudomonas syringae pv. actinidiae by four pairs of published primers. Lane $\mathrm{M}, 2 \mathrm{~kb}$ DNA ladder; lane 1-3, strains of $P$. syringae $p v$. actinidiae, $P$. syringae $p v$. syringae and $P$. syringae listed in Table 1 amplified with primer KNF/KNR, respectively; lane 4-6, lane7-9, lane 1012 , the same tested strains as lane 1-3 amplified with primer PsaF1/PsaR2, ArgKF3/ArgKR4 and Ps.ITSF1/Ps.ITSR2, respectively.

Neera, 2009; Masuzaki et al., 2008; Kim et al., 2008; Mikolajczyk et al., 2008). In this experiment, the specific $1300 \mathrm{bp}$ fragment that was amplified by RAPD reactions was cloned and sequenced for designing the SCAR primers. Based on the sequences of the $1300 \mathrm{bp}$ fragment, a pair of SCAR primers (F7'/R7') was selected from the several pairs of designed primers to generate the $994 \mathrm{bp}$ single fragment only in the strains of $P$. syringae pv. actinidiae, but not in other strains and sterilized distilled water. The optimal annealing temperature of this pair of synthesized primers was found to be $56^{\circ} \mathrm{C}$. Then, for detection of inoculated kiwifruit trunk tissues, the result indicated that the genomic DNA of Pseudomonas syringae pv. actinidiae could be detected by the specific primers, no matter what stage the inoculated kiwifruit trunk tissues was. This result confirmed that the specific primers could detect the pathogenic bacteria from the host tissues and even diagnose the disease before any symptoms appears. Meanwhile, through the sensitivity test, the specific primers could successfully detect the pathogen genome DNA at the concentration of $100 \mathrm{fg} / \mu \mathrm{l}$. That means the specific primers could detect the pathogen at a very low concentration of the genomic DNA, which makes it possible to detect the disease at its early latent period. In addition, this experiment also used four pairs of published primers to amplify the strains of $P$. syringae $p v$. actinidiae, $P$. syringae pv. syringae and P.syringae, in order to compare the primers designed in this study with the published primers and prove the specificity of the designed primers to detect the bacterial canker of kiwifruit in Sichuan. The result of comparison showed that the published primers were not specific to $P$. syringe $p v$. actinidiae that was isolated from kiwifruit trees in Sichuan. Primer KNF/KNR and primer Ps.ITSF1/Ps.ITSR2 detected other Pseudomonad's common as well as $P$. syringae $p v$. actinidiae. And primer PsaF1/PsaR2 could hardly detect a fragment from the three tested strains as well as primer ArgKF3/ArgKR4.
Only the primers designed in this study were able to distinguish $P$. syringae $p v$. actinidiae from other similar pathovars or species that frequently isolated from the kiwifruit trees in Sichuan. The reason for the result may be the geographical differences the pathogenic bacteria's genomic DNA mutates so that those published primers cannot perfectly detect the bacterial canker of kiwifruit in Sichuan.

Compared with the traditional detection methods, the specific primers ( $\left.F 7^{\prime} / R 7^{\prime}\right)$ can greatly shorten the time of diagnosis and has higher accuracy and sensitivity. Moreover, the method is relatively simple, cheap and flexible, and has less intermediate procedures so that it can avoid unnecessary interference. Besides, it can detect the pathogen in the early latent period of the disease. Therefore, it can be used to inspect and quarantine the plants and plant products between the endemic area and non endemic areas in order to control the further spread of the kiwifruit canker. To some extent, the development of the primers for detection the pathogen of the kiwifruit canker also fills the gap of molecular detection of Pseudomonas syringae pv. actinidiae in China. Since the use of the primers designed in this study would make it possible to rapidly and precisely detect the $P$. syringae $p v$. actinidiae among the various germs that are similar to the pathogenic bacteria or frequently isolated from the kiwifruit trees, the development of the primers is expected to greatly contribute to the early diagnosis and control of the bacterial canker disease on kiwifruit.

\section{ACKNOWLEDGEMENTS}

This research was funded by the General Administration of Quality Supervision, Inspection and Quarantine of the People's Republic of China. The authors thank the Research Institute of Forestry Ecology, Environment and Conservation, Chinese Academy of Forestry, China for their kindly offer of the strains that were used in this research.

\section{REFERENCES}

Audy P, Braat CE, Saindon G, Huang HC, Laroche A (1996). A rapid and sensitive PCR-based assay for current detection of bacteria causing common and halo blights in bean seed. Phytopathology 86:361-366.

Cheng HY, Li Y, Wan SK, Zhang J, Ping Q, Li G, Xing JH (1995). Pathogenic identification of kiwifruit bacterial canker in Anhui. J. Anhui Agric. Univ. 22: 219-228. (in Chinese)

Demeke T, Sasikumar B, Hucl P, Chibbar RN (1997). Random amplified polymorphic DNA (RAPD) in cereal improvement. Maydica 42:133142.

De Wolf $H$, Blust R, Backeljiau T (2004). The use of RAPD in ecotoxicology: A review. Mutat. Res. 566:249-262.

Evans KM, James CM (2003). Identification of SCAR markers linked to powdery mildew resistance in apple. Theor. Appl. Genet. 106:11781183.

Fang YZ, Zhu XX, Liao XG (1990). Survey and Research of kiwifruit disease in Hunan. Southwest Hortic. 35:28-29. (in Chinese). 
George JR, Vanneste JL, Cornish DA, Pushparajah IPS, Yu J, Templeton MD, Everett KR (2010). Detection of Pseudomonas syringae $\mathrm{pv}$. actinidiae using polymerase chain reaction (PCR) primers based on the 16S-23S rDNA intertranscribed spacer region and comparison with PCR primers based on other gene regions. Plant Pathol. 59:43-46.

Hernandez P, Martin A, Dorado G (1999). Development of SCARs by direct sequencing of RAPD products: A practical tool for the introgression and marker assisted selection of wheat. Mol. Breed. 5:245-253.

Karp A, Edwards KJ, Bruford M, Funk S, Vosman B, Morgante M Seberg O, Kremer A, Boursot P, Arctander P, Tautz D, Hewitt GM (1997). Molecular technologies for biodiversity evaluation: opportunities and challenges. Nat. Biotechnol. 15:625-628.

Kim GH, Yun HK, Choi CS, Park JH, Jung YJ, Park KS, Dane F, Kang KK (2008). Identification of AFLP and RAPD markers linked to anthracnose resistance ingrapes and their conversion to SCAR markers. Plant Breed. 127:418-423.

Koh YJ, Lee DH (1992). Canker of kiwifruit by Pseudomonas syringae pv. morsprunorum. Korean J. Plant Pathol. 8:119-122.

Koh YJ, Chung HJ, Kim JH (1993). Blossom rot of kiwifruit caused by Pseudomonas syringae. Korean J. Plant Pathol. 9:300-303.

Koh YJ, Park SY, Lee DH (1996). Characteristics of bacterial canker of kiwifruit occurring in Korea and its control by trunk injection. Korean J. Plant Pathol. 12:324-330.

Koh YJ, Seo JK, Lee DH, Shin JS, Kim SH (1999). Chemical control of bacterial canker of kiwifruit. Plant Dis. Agric. 5:95-99.

Koh YJ, Nou IS (2002). DNA Markers for Identification of Pseudomonas syringae pv. actinidiae. Mol. Cell 13:309-314.

Liu SJ, Tang XF, Wang ZS (1996). Incidence regularity of kiwifruit bacterial canker in Cangxi of Sichuan. China Fruit 1:25-26. (in Chinese).

Lin YJ, Gao RX (1995). Survey and Identification of Actinidia spp. Diseases in Fujian, China. J. Fujian Agric. Univ. 24:49-50. (in Chinese)

Mazarei M, Mostofipour P (1994). First report of bacterial canker of kiwifruit in Iran. Plant Pathol. 43:1055-1056.

Meetu G, Neera BS (2009). Heavy metal induced DNA changes in aquatic macrophytes: Random amplified polymorphic DNA analysis and identification of sequence characterized amplified region marker. J. Environ. Sci. 21:686-690.

Masuzaki SI, Miyazaki T, McCallum JA, Heusden S, Kik C, Yamashita KI, Tashiro Y, Yamauchi N, Shigyo M (2008). Conversion of chromosome-specific RAPDs into SCAR-based anchor markers for onion linkage maps and its application to genetic analyses in other Allium species. Sci. Hortic. 115:323-328.

Mikolajczyk K, Dabert M, Nowakowska J, Podkowinski J, Poplawska W, Bartkowiakbroda I (2008). Conversion of the RAPD OPC02 1150 marker of the Rfo restorer gene into a SCAR marker for rapid selection of oilseed rape. Plant breed. 127:647-649.
Neale DB, Harry DE (1994). Genetic mapping in forest trees: RFLPs, RAPDs and beyond. Ag. Biotech. News Inform. 6:107-114.

Opgcnorth DC (1983). Pseudomonas canker of kiwifruit. Plant Dis. 67:1283-1284.

Paran I, Michelmore RW (1993). Development of reliable PCR-based markers linked to downy mildew resistance genes in lettuce. Theor. Appl. Genet. 85:985-993.

Parry DW, Nicholson P (1996). Development of a PCR assay to detect Fusarium poae in wheat. Plant Pathol. 45:383-391.

Scortichini M (1994). Occurrence of Pseudomonas syringae pv. actinidiae on kiwifruit in Italy. Plant Pathol. 43:1035-1038.

Serizawa S, Ichikawa T, Takikawa Y, Tsuyumu S, Goto M (1989). Occurrence of bacterial canker of kiwifruit in Japan: description of symptoms, isolation of the pathogen and screening of bactericides. Ann. Phytopathol. Soc. Jpn. 55:427-436.

Sorensen KN, Kim KH, Takemoto JY (1998). PCR detection of cyclic lipodepsinonapeptide-producing Pseudomonas syringae pv. syringae and similarity of strains. Appl. Environ. Microbiol. 64:226-230.

Sun BJ, Li ZL, Li ZX, Luo SB, Li YY (2010). Reasons for SCAR Conversion Failure and its Remedies. Mol. Plant Breed. 8:589-594.

Takikawa Y, Serizawa S, Ichikawa T, Tsuyumu S, Goto M (1989). Pseudomonas syringae pv. actinidiae pv. nov.: the causal bacterium of canker of kiwifruit in Japan. Ann. Phytopathol. Soc. Jpn. 55:37-44.

Templeton MD, Reinhardt LA, Collyer CA, Mitchell RE, Cleland WW (2005). Kinetic analysis of the L-ornithine transcarbamoylase from Pseudomonas savastanoi pv. phaseolicola that is resistant to the transition state analogue (R)- N delta -(N'-Sulfodiaminophosphinyl)-Lornithine. Biochem (Washington), 44:8-15.

Ushiyama K (1993). Studies on the epidemics and control of bacterial canker of kiwifruit caused by Pseudomonas syringae pv. actinidiae. Bull. Kanagawa Hortic. Exp. Stn. 43:1-76.

Wang ZS, Tang XF, Liu SJ (1992). Identification of the pathogenic bacterium for bacterial canker on Actinidia in Sichuan. J. Southwest Agric. Univ. 14:500-503. (in Chinese)

Williams JGK, Kubelik AR, Livak KJ, Rafalski JA, Tingey SV (1990). DNA polymorphisms amplified by arbitrary primers are useful as genetic markers. Nucleic Acids Res. 18:6531-6535.

Young JM, Cheesmur GJ, Welham FV, Henshall WR (1988). Bacterial blight of kiwifruit. Ann. Appl. Biol. 112:91-105.

Zhu XX, Fang YZ, Liao XG (1993). Research of the pathogen of kiwifruit bacterial canker. Hunan Agric. Sci. 6:31-33. (in Chinese). 